Western University

Scholarship@Western

Department of English Publications

English Department

Spring 2010

\title{
Artifacting an Intercultural Nation: Theatre Replacement's BIOBOXES
}

Kim Solga

The University of Western Ontario

Follow this and additional works at: https://ir.lib.uwo.ca/englishpub

Part of the English Language and Literature Commons, and the Theatre and Performance Studies Commons

Citation of this paper:

Solga, Kim, "Artifacting an Intercultural Nation: Theatre Replacement's BIOBOXES" (2010). Department of English Publications. 1. https://ir.lib.uwo.ca/englishpub/1 
$<$ CAMT>Artifacting an Intercultural Nation

$<$ CAAU $>$ Kim Solga

<CATEXT>Cindy Mochizuki is sitting so close to me that I can smell her breath. Her eyes, full of tension and surprise, meet mine; I feel my own eyes open wider, my spine stiffen. I snap to attention in part out of respect for this performer's address, in part out of a childish fear that she might see me slouching. Because Cindy and I are in this together, and I see how clearly she sees me. How could she not? I am her only audience member, and we are alone together in the "Japanese Box," a tiny puppetstyle theatre that accommodates only my body, her head, and the stage of delicate miniatures she has built for her performance. Cindy performs grief and mourning, hope and longing: a girl, new to Canada (new enough, anyway), has lost a loved one. She struggles to fit into her new space, her new words. She takes a picture of me. She takes pictures of all the people around her and asks me to look at the snapshots with a tiny flashlight. I hold the pictures, awkwardly, until she quietly asks for them back. She follows the birds, and so do I. She asks me to light some incense for her loved one. Then she gives me a tiny pebble as a souvenir.

As I record these disconnected memories I know I'm not painting a very good picture. The truth is I don't remember much 
of Cindy's performance, in part because I chose to listen to half of it in Japanese, a language I don't speak at all. The option was there: affix the language card and hear her words in English or Japanese, switching at will. I'm not entirely sure why I kept switching into Japanese. I think I felt bad that the character in the narrative, still so unsure in her English, should have to keep using it just for me. Or perhaps I sensed it would be somehow more respectful to hear the performance in its "native" language. In hindsight, I know I was wrong: my choice might have seemed somehow generous at the time but it proved unhelpful, provoked by my useless guilt as an English-speaking, native-born Canadian. Ultimately, the language barrier stopped me from experiencing Cindy's performance fully. Now I barely know enough of it to pass it on.

This is BIOBOXES: Artifacting Human Experience, a theatrical installation created in 2006-2007 by Vancouver's Theatre Replacement. BIOBOXES is "a collection of one-person shows for one-person audiences that take place in an intimate theatre: a box worn on the actors' shoulders." It is based on the life experiences of a series of first-generation Canadians living in Vancouver, channeled through the creative work of a group of artists of similar ethnic background and translated into what Theatre Replacement calls "a new form of documentary performance" that has more in common with the "museum" and the 
"photo album" than it does with the proscenium arch (or the black box; Theatre Replacement 2009a). Audiences enter the "host" theatre space in small groups and sit on the periphery of the stage. A video of interviews with the performance's subjects plays on a makeshift screen, entertaining us as we wait. On the stage (or, more accurately, in the middle of a working rehearsal space that, under different circumstances, might be a stage), six actors in white lab coats prepare their boxes for the next round of play. En masse, they approach us: they call us by name, offer a warm handshake. This welcome is utterly, disarmingly sincere. While the performers are clearly "on," they are also clearly not in character. They tell us their names; they explain the workings of their boxes so that we might feel comfortable and safe; they answer all questions without hesitation. Then they disappear around back, pop heads into puppet spaces, and begin.

BIOBOXES unsettled me like no other performance I have ever attended.1 I felt unhinged somehow, turned over. As I left each

1. I saw BIOBOXES for the first time at the Dorothy Somerset Theatre on the University of British Columbia campus in Vancouver, $\mathrm{BC}$, on 1 June 2008. I saw it again at the Theatre Centre in Toronto on 2 May 2009. BIOBOXES was created by Anita Rochon, Marco Soriano, Paul Ternes, Cindy Mochizuki, Donna 
box my body felt different: I was at turns depressed and exhilarated. And I make these claims not naively: like most performance scholars, I travel regularly to see theatre and have attended plenty of unconventional performances in the oddest places imaginable. So why this show, why now? I suspect it has something to do with Cindy, and with my sense that, while trying to be polite and respectful to her "heritage" I somehow missed the story she was telling; that even as I took active part in that story, had my own image archived among its remains, I was not, could not be, easily absorbed into its fabric. As I work through this hunch, I want to position BIOBOXES in relation to two contemporary debates in Canadian and American performance studies. In Canada: the debate about what constitutes "multicultural" performance, and what performing "intercultural" experience in the contemporary, multicultural nation could look like. And in the wider discipline: the debate over what constitutes an ethically, socially, and politically productive act of theatrical "witness"-what it means to look at the stage, what intersubjective experiences might, for the greater good, obtain there, and (perhaps most urgently) what it means for us,

Soares, and Una Memisevic; and performed by Marco Soriano, Paul Ternes, Cindy Mochizuki, Donna Soares, Una Memisevic, Anita Rochon, and Samantha Madely. 
as theatre and performance scholars, to look at the audience looking at the stage and to dream the politics of that contact zone.

BIOBOXES is basically a collection of Canadian immigration stories, exactly the kind of stuff that an officially multicultural nation (as Canada has been to varying degrees since 1971) ${ }^{2}$ typically lauds in order to confirm the benevolence of the open-armed state. Theatre Replacement's program note describes the work of making BIOBOXES as follows: <CAEX>The stories in BIOBOXES are all derived from interviews with first-generation Canadians currently living in Vancouver. Each creator-performer conducted a series of bilingual interviews with a first-generation Canadian of their respective heritage. The interviewees were also asked to bring along three objects of importance to them, which are incorporated into the boxes and accompanying video. [...] Over three weeks, the creative team developed these shows working through a process of

\footnotetext{
2 The white paper "Multiculturalism within a Bilingual Framework" was introduced by Prime Minister Pierre Trudeau in 1971 as an attempt to include the concerns and experiences of "ethnic" minorities within Canada's ongoing bilingual (English-French) negotiations. "Multiculturalism" as official Canadian social policy was first formalized as part of the Charter of Rights and Freedoms in 1982, and, on 21 July 1988, royal assent was given to the Canadian Multiculturalism Act. For a comprehensive reading of official Canadian multiculturalism within a performance framework, see Knowles 2009.
} 
transcribing, selecting and editing text, storyboarding, building, rehearsing, and now, performance. (2009b)

<CATEXT>In a recent article about "the performance ecology" of Toronto's intercultural theatre scene, Ric Knowles differentiates between what he calls Canadian "multicultural texts"-"the policies, documents, and official discourses of Canadian multiculturalism," as well as the theatrical events and social performances, often funded by government diversity programs and framed by civic heritage spectacles, that are sanctioned by those texts-and "intercultural" performance work, made by a host of primarily young artists of color, that seeks to disrupt, reinterpret, question and challenge the myths of "mosaic" harmony on which Canada's multicultural nationhood, and conventional forms of "heritage" theatre, are built (2009:73). I find this binary framework a powerful one for critiquing both contemporary Canadian performance and the government networks that fund it, but I also find that, ironically, I cannot fit BIOBOXES easily into it. This show, provocatively, plays both sides of the multicultural/intercultural divide. On the surface (and in the program), BIOBOXES reads as "officially" multicultural: it's a performance about heritage. It's memorydriven, a bit nostalgic, and resolutely hyphenated: firstgeneration Canadians, Japanese-Canadians and German-Canadians and French-Canadians, tell their stories to (?)-Canadians of all 
shapes and sizes. But it's also much more than this. It's a performance event in which form both challenges and buttresses content, celebrates "heritage" and its nostalgic impulses while also subtly meddling with the conventional multicultural performance structure into which BIOBOXES so easily seems to slide.

BIOBOXES stages its very own multicultural archive via its intimate interviews with "new" Canadians and the remnant items they have been asked to leave behind. And it tells some painfully sentimental stories of arrival, rejection, and, finally, acceptance. In the Italian box, for example, a young wife leaves her sun-dappled childhood to start a new life in rainy Vancouver. The winter weather wears her down; her job wears her down; her husband wears her down. She makes a journey back "home" but finds herself eager to return to her new home, Canada. As her plane lands, the mountains glitter like jewels through her window. But BIOBOXES also tells totally unexpected stories, stories from immigrants that have nothing to do with immigration, that are jarring and uncanny for how otherwise familiar they seem: about a family breaking up; about a woman suffering from acute hypochondria; about illness and loss; about dinner. And, of course, never far from the edge of perception: about conducting an interview, building a stage, turning all of 
these stories into theatre, entertainment, someone else's (my) gratification.

From box to box this show stages both the multicultural archive and the intercultural repertoire; the labor required to sustain the former bleeds relentlessly into the latter as Cindy and her colleagues set about their virtuostic work. Certain of our well-trafficked narratives about what it is to be an "immigrant" nation, to be a "haven" for refugees from around the globe, appear alongside the unexpected twists and turns of ordinary lives lived (by the characters, of course, but also by the actors I see, always see, in front of me) within the impossibly idealistic expectations of official multiculturalism. Expectations that you will become Canadian while also retaining the memory of elsewhere, in part because we need your "elsewhere" to become part of our national "show"; expectations that you'll always be just a little bit different, but that your difference will be a good thing, a neutral thing, because we will all share difference as a fulcrum of our national identity. All this stuff collides with my own experience of nationhood in the tiny space between performer and spectator. And in this space-claustrophobic and warm and weirdly too close to difference for comfort-I have to decide what "multiculturalism" means to me, to us, right here, right now. And I have to reckon with the work it requires. 
If you're a spectator like me-at once proud and critical of my country; at once susceptible to myth and eager to deconstruct it-BIOBOXES will pull you several ways at once. In its physical setup it produces a level of intimacy that makes anything less than full body immersion almost impossible. Not only are the performers close enough to touch, but most boxes require my active participation. This requirement causes me occasional anxiety. In the Japanese box I have trouble juggling all of Cindy's photographs, worry I will drop them. In the French box I am asked to write a letter from mother to son (in French! Is my spelling okay?). In the German box a drill comes through a styrofoam wall at my eye level and, just as I fear it's going to graze me, the debris falls into my lap. In each case I am hyperaware of how important my participation is: the show cannot continue without me. I am squeezed into a story not of my own making, but I'm also oddly unfazed by this. As with Cindy's Japanese, I feel, simply, compelled to act: to keep things moving, to honor the story, and to get to the end. And I wonder: is this what it means not just to "watch" another immigrant story but to bear witness to the struggle of its telling, the awkwardness of its hearing, in the oddly crowded space between her and me?

The Canadian Drama course I teach at the University of Western Ontario is subtitled "Performing an Intercultural 
Nation." We talk about Canadian political myths, about the role theatre and performance can play in generating a new national discourse around ethnic and racial diversity, and we talk about witness. What does it mean to encounter the other at the theatre, especially our national "others"? To be touched, perhaps changed (forever?) by something that happens both up there, on stage, and inside me, in my brain and body? Roger Simon, writing about the processes of historical witness, distinguishes between "memory as a component of the founding ethos of national or communal identity"-for example, a collective memory deployed by official public discourses in order to generate belief in an unbreachable, carefully bounded collective selfhood-and memory "as a condition for the learning necessary to sustain the prospect of democracy" (2005:5). This latter form of memory, Simon argues, can only be enabled by one's "attentiveness to an otherness" and to "the question of to what and to whom I must be accountable" (4-5). Is that what happened in Cindy's box? I ask myself later, after. Did I realize a necessary accountability to her, but then somehow refuse my attentiveness? Did Cindy ask for my witness, and in my eagerness to give it, did I fail her?

Right now in theatre and performance studies the discourses of empathy and witness are every-present; we're working through a moment in which many of us seek, for better or worse, to claim 
that politically progressive performance demands audiences to feel against the grain of the self and toward the other in a profoundly ethical way. ${ }^{3}$ I want to make a similar claim for BIOBOXES - I truly do. I want to say that it forces audiences into intimate, visceral collision with actors and "their" stories and thus provokes a deeply personal unsettlement that, in turn, unsettles our performative encounter with Canada's multicultural script. And on some level, I suspect the show does just this. At least, for some audience members. But for many others, I suspect it does something else.

The trouble is, I'm not sure - whatever my scholarly self would like to claim - that BIOBOXES necessarily provokes an act of witness simply by sitting me down two feet from a performer's face, handing me a brace of photos (or a pen) and commanding me to look (or to write). Rather, in working through my own watching experience via this brief article, I have come to suspect that BIOBOXES enacts the politics of defining a genuinely democratic act of theatrical witness-enacts the politics inherent in the relationship among actor, subject, and witness within Canadian multicultural performance right now-by requiring every spectator to make specific choices about how to

3 I think of Jill Dolan's compelling Utopia in Performance: Finding Hope at the Theatre (2005) as a landmark text here, though there are many others, including David Krasner's "Empathy and Theater" (2006). 
watch, how deeply to get involved. Maybe I have to take the photos, but I don't have to look at them. Maybe I have to hold the pen, but I don't have to write. Maybe I'll listen in French, and really, truly try to hear. Or maybe I'll listen in French because I don't know French all that well (many Canadians do not, despite the mythology of official bilingualism), and I'm a bit uncomfortable, and I really just need to shut off for a minute.

BIOBOXES is in every way about the choices we make when we go to the theatre-about the usually invisible ways in which we decide when and how to look at our "others". Because I can hardly claim to know what goes on in every box, every time (the spectator is, to my prying scholarly eyes, brilliantly opaque here), I find myself prompted to think carefully about what's at stake in calling these small boxes-theatres reduced to their barest essentials-potentially utopic spaces, spaces of inherently democratic witness. Because the truth is, BIOBOXES made me kind of uncomfortable. I was constantly watching myself watching (see Levin et al), analyzing my own experiences of engagement even as my body gave over, sometimes reluctantly and sometimes willingly, to each performer. And the truth is, I enjoyed listening to Cindy speak Japanese; her story didn't matter all that much to me in the end. In the end, BIOBOXES unnerved me because it made me look, really look, at myself-at 
the work I do in the theatre, at the work I do as a theatre scholar, and at the labor I expend, as a Canadian citizen, in support of and in challenge to the cultural spectacles through which this country is evolving its contemporary cosmopolitan identity.

\section{$<$ REF $>$ References}

Dolan, Jill. 2005. Utopia in Performance: Finding Hope at the Theater. Ann Arbor: University of Michigan Press. Knowles, Ric. 2009. "Multicultural Text, Intercultural Performance: The Performance Ecology of Contemporary Toronto." In Performance and the City, ed. D.J. Hopkins, Shelley Orr, and Kim Solga, 73-91. Basingstoke: Palgrave MacMillan.

Krasner, David. 2006. "Empathy and Theater." In Staging Philosophy: Intersections of Theater, Performance, and Philosophy, ed. David Krasner and David Z. Saltz. Ann Arbor: University of Michigan Press. Levin, Laura, Marlis Schweitzer, Kim Solga, Jenn Stephenson, and Belarie Zatzman. 2009. "Performing Outside of the Box." Canadian Theatre Review, Winter 2009:61-67.

Simon, Roger. 2005. The Touch of the Past: Remembrance, Learning, and Ethics. Basingstoke: Palgrave MacMillan. Theatre Replacement. 2009a. "Past Projects: BIOBOXES." http://www. theatrereplacement.org (18 May). 
Theatre Replacement. 2009b. BIOBOXES program note. 